\title{
EXTENDED COLD STORAGE OF WINTER PEARS BY MODIFIED ATMOSPHERE PACKAGING ${ }^{1}$
}

\author{
MOISES ZUCOLOTO ${ }^{2}$, LUCIMARA ROGERIA ANTONIOLLI ${ }^{3 *}$, \\ DALMO LOPES DE SIQUEIRA ${ }^{4}$, ANA BEATRIZ COSTA CZERMAINSKI ${ }^{3}$
}

\begin{abstract}
The aim of this work was to evaluate the effect of passive modified atmosphere packaging (MAP) on the maintenance of fruit quality during the extended storage of 'Rocha' and 'Packham's Triumph' pears. Fruit were packed in linear low density polyethylene $(100 \mu \mathrm{m})$, with $6 \%$ BIF 1500 additive placed into perforated plastic boxes and kept at $0 \pm 1{ }^{\circ} \mathrm{C}$ and $90 \pm 5 \% \mathrm{RH}$ for up to 180 days. MAP reduced weight loss by $14.8 \%$ for 'Rocha' and $11.5 \%$ for 'Packham's' pears after 180 days in cold storage and retained the green color of the skin, which means that the yellowing visual perception was delayed in 60 and 90 days for 'Rocha' and 'Packham's' pears, respectively. A strong softening was observed for 'Packham's' pears after being kept for 150 days at $0^{\circ} \mathrm{C}$ followed by 5 days at room temperature, which did not limit the storage of both pear cultivars under modified atmosphere packaging. MAP created by linear low density polyethylene $(100 \mu \mathrm{m})$, with $6 \%$ BIF 1500 additive extended in 30 days the cold storage for 'Rocha' and 60 days for 'Packham's' pears.
\end{abstract}

Index terms: Pyrus communis L., 'Rocha', 'Packham's Triumph', polyethylene film, water loss, acceptance.

\section{EXTENSÃO DO PERÍODO DE ARMAZENAMENTO REFRIGERADO DE PERAS EUROPEIAS POR MEIO DO USO DE ATMOSFERA MODIFICADA}

RESUMO - O objetivo deste trabalho foi avaliar a eficiência da atmosfera modificada na manutenção dos atributos de qualidade e na extensão do armazenamento refrigerado de peras 'Rocha'e 'Packham's Triumph'. Os frutos foram acondicionados em filme de polietileno de baixa densidade linear $(100 \mu \mathrm{m})$ com aditivo BIF $1.5006 \%$ no interior de caixas plásticas vazadas e mantidos a $0 \pm 1{ }^{\circ} \mathrm{C}$ e $90 \pm 5 \%$ UR por até 180 dias. A atmosfera modificada reduziu em 14,8\% a perda de massa de peras 'Rocha' e em 11,5\% a de peras 'Packham's', após 180 dias de refrigeração, e mostrou-se útil na preservação da coloração verde dos frutos, retardando em 60 e 90 dias a percepção visual do amarelecimento da casca de peras 'Rocha e Packham's', respectivamente. Houve amolecimento excessivo da polpa de peras 'Packham's' controle após 150 dias a $0{ }^{\circ} \mathrm{C}$, seguidos por 5 dias a $20^{\circ} \mathrm{C}$, o que não limitou o armazenamento das peras de ambas as cultivares sob atmosfera modificada. A atmosfera modificada proporcionada pela embalagem de polietileno de baixa densidade linear $(100 \mu \mathrm{m})$ com aditivo BIF $1.5006 \%$, proporcionou a extensão de 30 dias no período de armazenamento refrigerado de peras 'Rocha' e de 60 dias para 'Packham's Triumph'.

Termos para indexação: Pyrus communis L., 'Rocha', 'Packham’s Triumph', filme de polietileno, perda de massa, aceitabilidade.

\footnotetext{
${ }^{1}$ (Paper 148-15). Received in: 29-05-2015. Accepted for publication: 30-11-2015.

${ }^{2}$ Professor at the Department of Agricultural and Biological Sciences, Federal University of Espírito Santo, BR 101, km 60, 29932-540, São Mateus-ES, Brazil. E-mail: moiseszucoloto@hotmail.com

${ }^{3}$ Researchers - Brazilian Agricultural Research Corporation (EMBRAPA GRAPE AND WINE), Bento Gonçalves-RS, Brazil. Email: lucimara.antoniolli@embrapa.br; ana.czermainski@embrapa.br (*Corresponding author.)

${ }^{4}$ Professor at the Department of Plant Science, Federal University of Viçosa (UFV), Viçosa - MG, Brazil. E-mail: siqueira@ufv.br
} 


\section{INTRODUCTION}

Pear production represents $2.5 \%$ of world fruit production and is growing every year. For the 2013/14 crop, official numbers point to a record production of about 23.1 million tons. Brazil imports annually about 230,000 tons of pears, placing the fruit in a prominent position in the country's trade balance (CIPRIANI, 2014). Despite the large consumer market, the Brazilian production of pears is still small. Among European cultivars, 'Rocha' and 'Packham's Triumph' stand out as promising for the southern region of Brazil, where climatic conditions favor fruit cultivation (Wrege et al., 2006).

Cold storage extends shelf life by reducing metabolic activity and consequently delays ripening. According to ZUCOLOTO (2012), 'Rocha' and 'Packham's Triumph' pears have good storage life, allowing conservation for up to 100 days at $0 \pm$ $1{ }^{\circ} \mathrm{C}$ and $90-95 \% \mathrm{RH}$, depending on the maturity at harvest.

Modified atmosphere (MA) and controlled atmosphere (CA) storage systems are used to complement cold storage in order to delay ripening, reduce physiological disorders and prevent the incidence of rot in fruits and vegetables. MA has a similar potential to CA on maintaining the quality of vegetables, without, however, high investments in infrastructure and instrumentation (WANG; SUGAR, 2013). Currently, the packaging technology aims not only to meet the classic functions of containing, protecting, and selling, but also of interacting with the product, as the active packaging (ZHU, 2014). Thus, while maintaining moisture, reducing skin darkening and the incidence of post-harvest diseases, various packages have additives capable of removing ethylene around the product, increasing the storage period as a result of delayed ripening (ZHU, 2014).

NATH et al. (2011) evaluated various packages: low-density polyethylene $(0.025$ $\mathrm{mm})$, polypropylene $(0.025 \mathrm{~mm})$, linear low density polyethylene $(0.0125 \mathrm{~mm})$ and highdensity polyethylene $(0.025 \mathrm{~mm})$ with or without perforations in the packaging of 'Lagoon' pears in ambient conditions of $25 \pm 2{ }^{\circ} \mathrm{C}$ and $65 \pm 5 \%$ relative humidity. The authors found that lowdensity polyethylene package $(0.025 \mathrm{~mm})$ without perforations extended the storage period for up to fifteen days and reported that packages were effective in reducing weight loss, maintaining firmness, color and nutrients of fruit. Additionally, CHENG et al. (2015) observed reduction in internal browning of Ya-Li pears during cold storage through the use of modified atmosphere.

The aim of this study was to evaluate the efficiency of passive modified atmosphere provided by linear low density polyethylene packaging (100 $\mu \mathrm{m}$ ) with $6 \%$ BIF 1500 in the maintenance of quality attributes and extension of cold storage of 'Rocha' and 'Packham's Triumph' pears.

\section{MATERIAL AND METHODS}

'Rocha' and 'Packham's Triumph' pears were harvested from a commercial orchard located in São Francisco de Paula-RS. Plants are grafted on 'Adams' quince and the trees are trained as central leader system. The spacing between plants is $0.50 \mathrm{x}$ $4.0 \mathrm{~m}$, in a total of 5,000 plants / ha.

Before starting harvest, monitoring the firmness of 20 randomly picked fruit was held for about a month. Harvest was held on January 25, 2011 for both cultivars when average firmness of 67.61 and $74,69 \mathrm{~N}$ for 'Rocha' and 'Packham's Triumph' pears, respectively, was recorded.

Fruit were preselected in the field for size and absence of damage. Then, they were placed in trays into plastic boxes model $\mathrm{CN}-60$ with $60 \mathrm{~L}$ capacity and dimensions of $28 \times 32 \times 52 \mathrm{~cm}$ internally protected by bubble wrap to avoid possible mechanical damage during transport. In the lab, pears were reselected to eliminate fruit with any type of defect and homogenize the batch regarding size.

Fruit of each cultivar were divided into two batches that were arranged in sorting trays into plastic boxes identical to those used in harvesting and submitted to the conditions below:

(1) Control or unpackaged fruit: plastic boxes were stored in a cold room at $0 \pm 1^{\circ} \mathrm{C}$ and $90 \pm 5 \%$ UR for up to 180 days;

(2) Passive modified atmosphere (MAP) or packaged fruit: sorting trays were placed inside a linear low density polyethylene package $(1.0 \times 0.5 \mathrm{~m})$ $(100 \mu \mathrm{m})$ with $6 \%$ BIF 1500 additive (Bag It Fresh B.I.F. 1500, Magna Chemical Canada Inc.). Plastic packages were placed in boxes and stored in a cold room at $0 \pm 1^{\circ} \mathrm{C}$ and $90 \pm 5 \%$ RH for up to 180 days.

Each batch consisted of experimental material that was tested for periods of $0,30,60,90$, 120,150 and 180 days of cold storage followed by 5 days in simulated room temperature $\left(20 \pm 1^{\circ} \mathrm{C}\right)$. Each treatment was applied to forty-eight replicates consisting of pre-identified samples of six fruit. At each evaluation, 8 samples of 6 fruit were removed from the cold room. Half of them was evaluated and the other samples were transferred to a room at $20 \pm 1^{\circ} \mathrm{C}$ for evaluation after five days in order to 
simulate normal marketing conditions. The package was immediately removed at the end of each storage period, i.e., fruit remained under conditions identical to control fruit during five days at room temperature.

The following quality attributes were determined: weight loss, firmness, skin color, soluble solids (SS), $\mathrm{pH}$, titratable acidity, acceptance, difference-from-control test and purchase intention.

\section{Quality analysis}

Weight loss over time was determined using the following formula: FWL: \{(IFW - FFW) * 100 / IFW \} where: FWL: fresh weight loss (\%); IFW: initial fresh weight $(\mathrm{g})$ and FFW: final fresh weight (g).

Firmness was measured on both sides of the equatorial region of each fruit, removing a small skin area. Fruit Pressure Tester Meter (Mc Cormick, model FT327) with $8 \mathrm{~mm}$ probe was used. Data were presented in Newton $(\mathrm{N})$.

Skin color was individually obtained in the equatorial region of fruit with digital colorimeter (Konica Minolta model CR-410) using the $\mathrm{L} * \mathrm{a} *$ $\mathrm{b} *$ system. Chroma and Hue angle were calculated as: $\mathrm{C}=\left(\mathrm{a}^{* 2}+\mathrm{b}^{* 2}\right)^{1 / 2}$ and Hue $=\tan ^{-1}\left(\mathrm{~b}^{*} / \mathrm{a}^{*}\right)+\mathrm{k}$ $\left(\mathrm{k}=180\right.$, if $\mathrm{a}^{*}<0 ; \mathrm{k}=360$, if $\mathrm{b}^{*}<0$, and $\mathrm{k}=0$ if both are positive), respectively).

To measure the SS content, $\mathrm{pH}$ and titratable acidity, homogenized juice from fruit from each replicate was used. For the SS content, digital refractometer (Atago PR-101 Pallet) was used; $\mathrm{pH}$ was determined in digital $\mathrm{pH}$ meter (Marconi, PA200). Titratable acidity was measured by titrating juice $(10 \mathrm{~mL}$ of juice in $90 \mathrm{~mL}$ of distilled water) with $0.1 \mathrm{~N}$ sodium hydroxide to a $\mathrm{pH} 8.1$ (Marconi, PA 200) and results were expressed as percentage of malic acid according to methodologies described in the Analysis Manual from "Adolfo Lutz" Institute (IAL, 2008).

\section{Sensory analysis}

Pears were evaluated for acceptance by at least 30 untrained panelists from both sexes and age between 18 and 65 years. Pears were sliced at test time to prevent enzymatic browning and consequently any interference in the product acceptance. Coded samples were randomized and served to the panelists. For sensory evaluation, a 7-point hedonic scale was used, where $1=$ disliked very much, $2=$ disliked much, $3=$ disliked, $4=$ not liked nor disliked, $5=$ liked, $6=$ liked much, $7=$ liked very much (FERREIRA et al., 2000). Panelists were also asked to record their observations about each sample.

The difference-from-control test was performed to verify the difference between fruit submitted to MAP and the control fruit. A scale from 0 to 9 was used, where $0=$ no difference and $9=$ very large difference between samples.

From the frequency of scores given to samples of each treatment for acceptance and difference-from-control, an index associated with the scale of each test was calculated. The index amplitude is from 0 , which indicates no acceptance or no difference from the control to 100 , for maximum acceptance and maximum difference from the control.

The questionnaire concerning purchase intention was applied for pears from both cultivars kept in cold room for 180 days followed by 5 days in simulated room temperature. Regarding global appearance, assessors were asked about their willingness to buy pears with similar quality at market value. If the answer was not, they were asked if they would buy with 10,30 or $50 \%$ price off, or if they would not buy at all.

\section{Statistical analysis}

Both conditions per cultivar determined four 7 $\mathrm{x} 2$ factorial trials in a completely randomized design with four replicates. Based on the corresponding model, physical and chemical attributes such as PWL, flesh firmness, SS content, $\mathrm{pH}$ and titratable acidity were submitted to analysis of variance. According to the F test results for main effects and interactions between cold storage (CS) and time in simulated room temperature (SRT), polynomial regression analysis was performed for maintenance periods under low temperature and Tukey test for comparison of room temperature times. A joint analysis of two experiments of each cultivar under $2 \times 7 \times 2$ factorial design was performed to support the discussion and general comparison between the two conditions (control and MAP).

The five coordinates related to color were submitted to principal component analysis (PCA), using the average of treatments and taking into account the simple correlation among coordinates L, $\mathrm{C}$ and Hue. The acceptance index for each sample tested was compared to the pattern $\mathrm{p}_{0}=0.70$ by the t-test with approach to Normal. In the differencefrom-control test, differences from the standard, expressed in proportion, obtained for control and MAP were compared for each treatment and cultivar using the Wald test at 5\%.

For statistical analysis of the data, the SAS (Statistical Analysis System) version 9.2 was used. 


\section{RESULTS AND DISCUSSION}

MAP drastically reduced weight loss over the storage period for both 'Rocha' and 'Packham's Triumph' pears with values of $2.07 \%$ and $1.35 \%$, respectively, after 180 days of cold storage (figures 1A and 1C). In control fruit, weight loss progressively increased during cold storage, reaching $16.92 \%$ in 'Rocha' and $12.87 \%$ in 'Packham's Triumph' pears after 180 days (Figures 1B and 1D). Losses were significant when fruit were transferred to room temperature except for 30 days for both cultivars in both storage conditions (Figure 1).

Weight loss under MAP even after 180 days of cold storage followed by five days at room temperature did not exceed 6\% (Figures 1A and 1C). In contrast, unpackaged fruit reached $6 \%$ weight loss after 58 days of cold storage for 'Rocha' and after 72 days for 'Packham's Triumph' pears (Figures $1 \mathrm{~B}$ and 1D). According to MAHAJAN et al. (2010), losses of $6 \%$ fresh weight compromises appearance due to dehydration of the region near the peduncle. Damage can vary among different cultivars due to the intrinsic characteristics of fruits, especially skin thickness.

The smaller weight loss of fruit submitted to modified atmosphere is possibly due to the reduction of transpiration and the limited oxygen availability, thus decreasing breathing and hence the conversion of mass into energy. The results are consistent with NATH et al. (2011), who studied different packages for 'Lagoon' pears and found lower weight loss related to the use of non-perforated packaging. CALVO et al. (2002) found smaller weight loss for 'William's' pears in response to the use of controlled atmosphere with low oxygen levels $(0.5 \%)$, leading to the reduction of respiration and consequently lower weight loss.

In this work, it was found that MAP for up to 180 days did not cause weight loss to interfere with the overall appearance of fruit. Unpackaged 'Rocha' pears showed $14.11 \%$ weight loss after 150 days under low temperature. This value added to losses suffered after five days at room temperature reached $15.64 \%$ weight loss, without, however, compromising the overall appearance of fruit. However, after 180 days at $0^{\circ} \mathrm{C}$ weight loss was $16.92 \%$ and fruit had the overall appearance compromised (Figure 1). Control 'Packham's Triumph' pears showed $8.58 \%$ weight loss after 120 days at $0^{\circ} \mathrm{C}$ and $12.77 \%$ after 5 days at room temperature. However, appearance was not compromised. When fruit were kept for 150 days at low temperature, weight loss was $10.73 \%$ and no overall appearance compromising was noticed; however, when fruit remained for five days in simulated room temperature, weight loss reached $16.47 \%$ and damage became visible (Figure 1).

Weight loss causes economic losses, both by reducing fruit quality and by lower sales volume. Chitarra and Chitarra (2005) reported that some fruits have compromised marketing with weight loss of only $4 \%$, while others are effectively compromised with weight losses exceeding $7 \%$. In this work, MAP minimized fruit weight loss, ensuring satisfactory overall appearance and greater volume to be marketed in relation to control fruit. Even without the use of packaging, overall appearance was compromised when weight loss reached values higher than those reported by Chitarra and Chitarra (2005), which is probably due to the different behavior of species, and even varieties.

'Rocha' and 'Packham's Triumph' control fruit, after 180 days of cold storage followed by five days in simulated room temperature, showed severe skin wrinkling and increased sensitivity to mechanical damage that prevented the performance of physical, chemical and sensory analysis in that period.

A decrease in flesh firmness during cold storage for fruit from different cultivars was observed, with the presence or not of packaging; however, this reduction was lower in fruit submitted to modified atmosphere, both for 'Rocha' and 'Packham's Triumph' pears (Figure 2).

For 'Rocha' pears, reduction in firmness was observed after storage for 30 days at $0^{\circ} \mathrm{C}$ followed by five days at $20 \pm 1{ }^{\circ} \mathrm{C}$, both in MAP and in control fruit (figures 2A and 2B). Despite this reduction, the firmness value was higher than recommended by Isidoro and Almeida (2006), who suggested the ideal flesh firmness for consumption as approximately $20 \mathrm{~N}$. This value was only reached after fruit remain for 60 days at $0^{\circ} \mathrm{C}$ followed by five days at $20^{\circ} \mathrm{C}$, both for control fruit and those submitted to modified atmosphere.

'Packham's Triumph' pears required 60 days at $0{ }^{\circ} \mathrm{C}$ followed by five days at $20 \pm 1{ }^{\circ} \mathrm{C}$ to show reduction in firmness, both for fruit submitted to modified atmosphere and for control fruit (Figures $2 \mathrm{C}$ and 2D). Due to the great reduction in firmness for 'Packham's' pears during cold storage, firmness of control fruit after 150 days of storage did not differ from fruit after five days at room temperature (Figure 2D), since fruit were already softened even before being transferred to $20^{\circ} \mathrm{C}$. The excessive softening, particularly for 'Packham's' pears, can compromise the overall appearance of fruit, since the loss of flesh 
firmness is closely correlated to higher sensitivity and occurrence of mechanical damage (VILLALOBOSACUNA; MITCHAM 2008 ).

Coordinates Hue, $\mathrm{L}$ and $\mathrm{C}$ were used to obtain the first two principal components (PC1 and PC2), which explained $94 \%$ of the total variation for 'Rocha' and $96 \%$ of the total variation for 'Packham's' pears. In the dispersion of score points of PC1 and PC2 (Figure 3), the ellipses indicate groups of similar treatments regarding skin color characteristics according to the storage at $0{ }^{\circ} \mathrm{C}$ and $20^{\circ} \mathrm{C}$. Hue angle and $\mathrm{L}$ had high influence on scores according to PC1. The most decisive response for PC2 values was chromaticity. MAP slowed yellowing of pears stored for both cultivars. The distinction among groups was more evident for 'Rocha' (Figure $3 \mathrm{~A}$ ), in which the difference in Hue angle (CP1) and $\mathrm{C}$ (CP2) was larger at longer storage periods with or without modified atmosphere. 'Packham's Triumph' pears stored in MAP for up to 90 days remained close to $\mathrm{PC} 1$ in the initial evaluation (Figure 3B).

The average Hue values from 'Rocha' and 'Packham's' pears (Table 1) indicate the negative effect of storage, both at $0{ }^{\circ} \mathrm{C}$ and $20^{\circ} \mathrm{C}$. According to Almeida (2004), differences equal to or greater than 2.5 between Hue values are perceptible to the human eye. 'Rocha' pears showed this difference from 60 days in cold storage while yellowing was noticed only from 90 days for 'Packham's Triumph' pears. These results indicate MAP is a useful tool in maintaining fruit coloring.

There was a slight increase in the SS content for 'Rocha' pears during cold storage for both control fruit and those submitted to modified atmosphere (Figures 4A and 4B). The SS content throughout the storage period was in line with recommendations from the 'Rocha' Pear Growers Association ANP (1997), i.e., above 10 'Brix. 'Packham's' pears showed an increase in the SS content during cold storage, with subsequent reduction after 104 days when fruit was stored under modified atmosphere and 105 days for control fruit. Although there are no reports in literature regarding the optimal SS content for consumption of 'Packham's Triumph' pears, the levels observed in this study were sufficient to provide pleasant flavor to fruit, as shown by the acceptance test (Figures 4C and 4D ).

These findings are similar to those of Elgar et al. (1997), who observed an increase in SS content during cold storage of 'Buerre Bose' and 'Doyenne du Comice' pears. This fact is due to the starch hydrolysis and dehydration of fruit, leading to increased SS concentration. In addition, it can be attributed to the climacteric respiratory metabolism, where SS contents rise, reaching maximum values and from that moment, SS become energy substrate for transformation and post-harvest survival of fruits, causing a decrease at the end of the cold storage period (CHITARRA and CHITARRA, 2005).

There was no effect on the $\mathrm{pH}$ of pears from both cultivars. The overall average $\mathrm{pH}$ was $4.18 \pm$ 0.16 for 'Rocha' and $3.85 \pm 0.16$ for 'Packham's Triumph' pears.

Regardless of cultivar and use of packaging, the titratable acidity levels suffered slight increase followed by reduction to the end of the cold storage period. The maximum acidity values of packaged fruit occurred at day 131 for 'Rocha' and day 160 for 'Packham's Triumph' pears, whereas in control fruit, these values were found at days 122 and 100, respectively (Figure 5). The more gradual reduction at the end of the cold storage period noticed in MAP fruit may be due to the reduced respiration rate, caused by the use of packaging (NATH et al., 2011).

'Rocha' and 'Packham's Triumph' pears showed high acceptance rate after 180 days under cold storage followed by five days at room temperature ( 83.03 and 73.34 , respectively) (Table $2)$. At the same period, panelists reported that fruit had become juicy, with good texture and pleasant aroma. Control fruit from both cultivars were not submitted to the acceptance test due to excessive weight loss and poor overall quality.

According to panelists, pears from both cultivars stored with or without packaging for 30 days at $0{ }^{\circ} \mathrm{C}$ followed by five days at room temperature were immature, with high firmness, little or no flavor and astringent. This fact can be confirmed by the high firmness values (Figure 2) and low SS levels (Figure 3) observed at the same period. Control 'Packham's' pears had rejection after 150 days at $0{ }^{\circ} \mathrm{C}$ followed by five days at room temperature due to the unpleasant aspect caused by excessive skin dehydration, flesh softening and lack of flavor. 'Rocha' pears evaluated at the same period, although there were no reports regarding changes in the global aspect, were described as overripe, with little flavor and extremely softened.

By the difference-from-control test, MAP fruit showed higher differences $(p<0.05)$ than the control fruit when compared to standard (Table 3), with the only exception for 'Packham's' pears kept for 120 days at cold storage and five days at room temperature. Reports indicated that pears stored in MA, especially 'Packham's Triumph', were firmer, more acidic and with better overall appearance than control fruit, since they showed no signs of dehydration and the incidence of mechanical damage 
was minimal.

The purchase intention showed that $62 \%$ of assessors would buy 'Rocha' pears at market price. Only $3 \%$ of them would purchase them with $10 \%$ price off, $6 \%$ would buy with $30 \%$ price off, $3 \%$ would buy with $50 \%$ price off and $26 \%$ would not buy the fruit even with reduced price. The results indicate that even being kept for 180 days at low temperatures, fruit showed high acceptance with highlighted good shape and appearance. Aspects justifying rejection were the small size of fruit and the presence of russeting, which are intrinsic to the cultivar and can be aggravated by inadequate orchard management, being therefore unrelated to the postharvest treatment applied. For 'Packham's Triumph' pears, the purchase intention showed that $81 \%$ of assessors would buy pears at the market price, $3 \%$ would purchase them with $10 \%$ price off, $3 \%$ would buy with $50 \%$ price off and only $13 \%$ of consumers would not buy the fruit even with reduced price. The main factors responsible for the acceptance of fruit were shape and size. Moreover, the factor that determined rejection was skin color, described as excessively green.

The results, especially regarding to weight loss, flesh firmness and skin color maintenance, and high acceptance rates indicate the use of MAP as an alternative technology, especially for small growers who do not have a controlled atmosphere system for the storage of fruit for long periods. The MA storage system is easy to perform and only requires the cold room with proper temperature control, and appropriate polymeric film. Linear low density polyethylene film $(100 \mu \mathrm{m})$ with $6 \%$ BIF 1500 additive delayed the ripening of 'Rocha' and 'Packham's Triumph' pears and allowed cold storage for up to 180 days, which implies the possibility of

extending the supply of pears of high sensory quality.

TABLE 1 - Hue angle from 'Rocha' and 'Packham's Triumph' pears submitted or not to passive modified atmosphere and kept for 180 days in cold storage (CS) at $0 \pm 1{ }^{\circ} \mathrm{C}$ and $90 \pm 5 \% \mathrm{RH}$ followed by five days at simulated room temperature (SRT) $\left(20 \pm 1^{\circ} \mathrm{C}\right)$ (sample of 24 fruit).

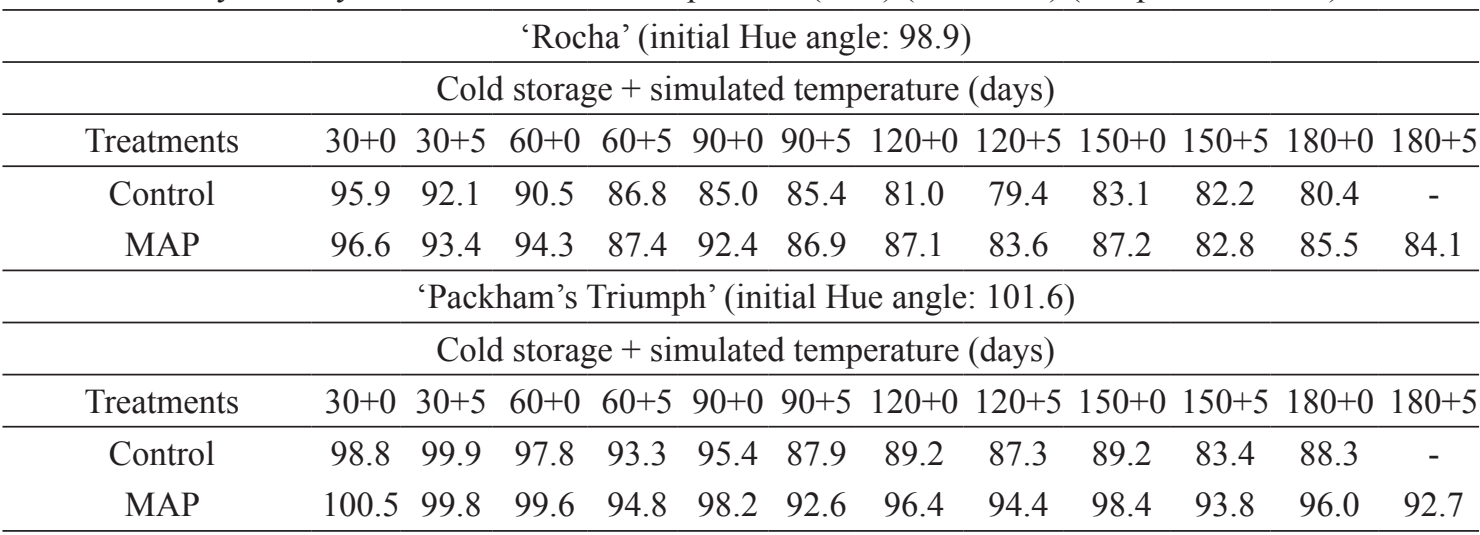

TABLE 2 - Acceptance index from 'Rocha' and 'Packham's Triumph' pears submitted or not to passive modified atmosphere and kept for 180 days in cold storage (CS) at $0 \pm 1{ }^{\circ} \mathrm{C}$ and $90 \pm 5 \% \mathrm{RH}$ followed by five days at simulated room temperature (SRT) $\left(20 \pm 1{ }^{\circ} \mathrm{C}\right)$.

\begin{tabular}{ccccccc}
\hline & & \multicolumn{2}{c}{ 'Rocha' } & \multicolumn{2}{c}{ 'Packham's Triumph' } \\
\cline { 3 - 4 } \cline { 5 - 6 } CS & SRT & Control & MAP & Control & MAP \\
30 & 5 & 78.70 & 62.49 & & $36.71^{*}$ & $48.75^{*}$ \\
90 & 5 & 74.82 & 56.67 & & 74.46 & 62.23 \\
120 & 5 & 61.98 & 60.18 & & $54.91^{*}$ & $50.91^{*}$ \\
150 & 5 & 59.12 & 63.39 & & 57.11 & 67.99 \\
180 & 5 & - & 83.03 & & - & 73.34 \\
\hline
\end{tabular}


* Acceptance indexes significantly lower than $0.70(\mathrm{p}<0.05)$.

TABLE 3 - Proportions resulting from the difference-from-control test applied to 'Rocha' and 'Packham's Triumph' pears submitted or not to passive modified atmosphere and kept for 150 days in cold storage (CS) at $0 \pm 1{ }^{\circ} \mathrm{C}$ and $90 \pm 5 \% \mathrm{RH}$ followed by five days at simulated room temperature (SRT) $\left(20 \pm 1{ }^{\circ} \mathrm{C}\right)$.

\begin{tabular}{|c|c|c|c|c|c|c|}
\hline \multirow{2}{*}{$\mathrm{CS}$} & \multirow{2}{*}{ SRT } & \multicolumn{2}{|c|}{ 'Rocha' } & \multicolumn{3}{|c|}{ 'Packham's Triumph' } \\
\hline & & Control & MAP & Control & MA & \\
\hline 30 & 5 & 22.01 & $68.75 *$ & 21.17 & 44.14 & $*$ \\
\hline 90 & 5 & 14.63 & $74.02 *$ & 21.50 & 71.18 & * \\
\hline 120 & 5 & 22.98 & $63.67 *$ & 37.92 & 57.18 & ns \\
\hline 150 & 5 & 25.18 & $65.25 *$ & 31.90 & 65.91 & $*$ \\
\hline
\end{tabular}

* Significant difference $(\mathrm{p}<0.05)$ from the standard.
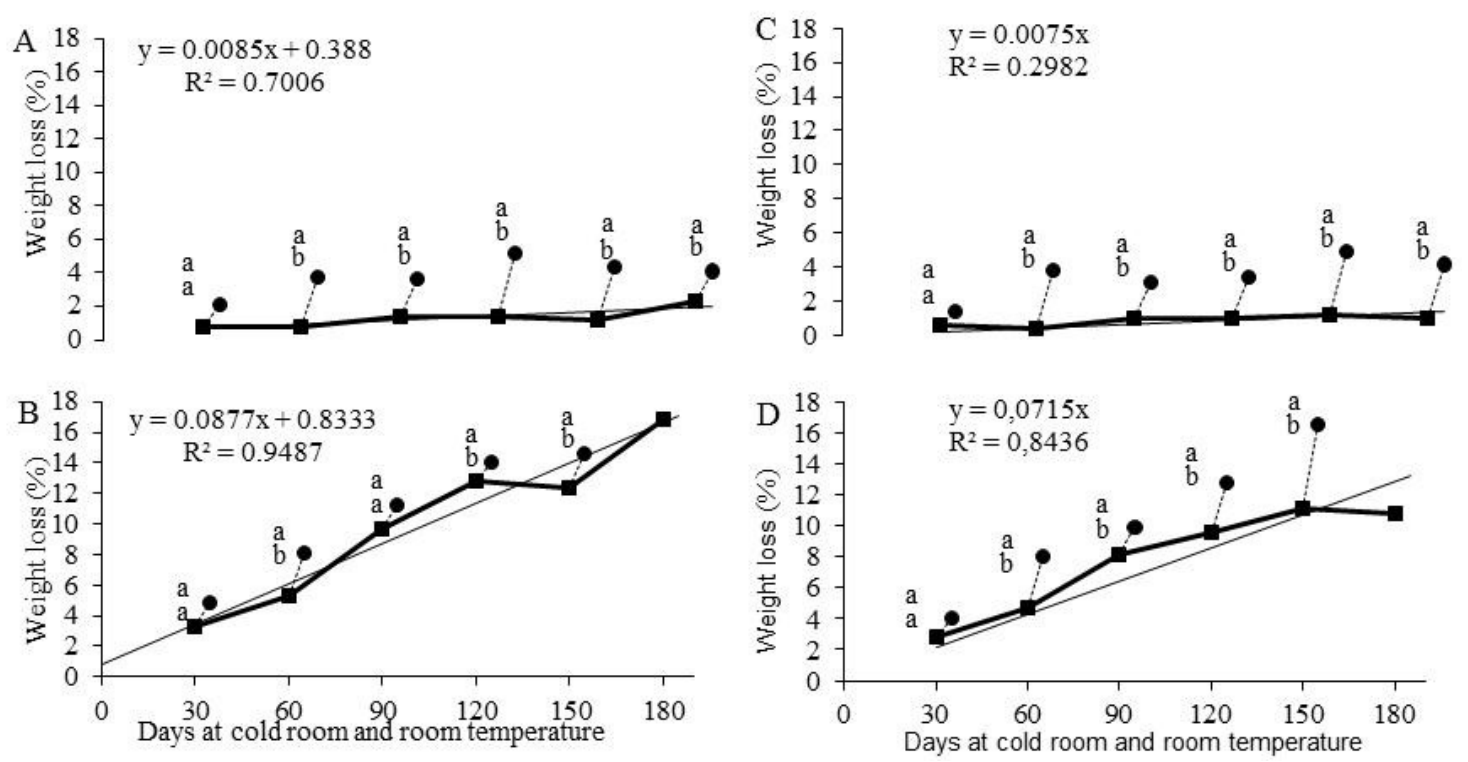

FIGURE 1 - Weight loss (\%) from 'Rocha' pears in MAP (A) and control (B) and 'Packham's Triumph' pears in MAP (C) and control (D) kept for 180 days in cold storage at $0 \pm 1{ }^{\circ} \mathrm{C}$ and $90 \pm 5 \%$ $\mathrm{RH}$ followed by five days at simulated room temperature $\left(20 \pm 1{ }^{\circ} \mathrm{C}\right)$. Equal letters vertically disposed indicate that the average obtained at room temperature and at $0{ }^{\circ} \mathrm{C}$ do not differ $(\mathrm{p}>$ 0.05 ). Adjusted regression equations for weight loss during cold storage is represented by the thinner solid line. 

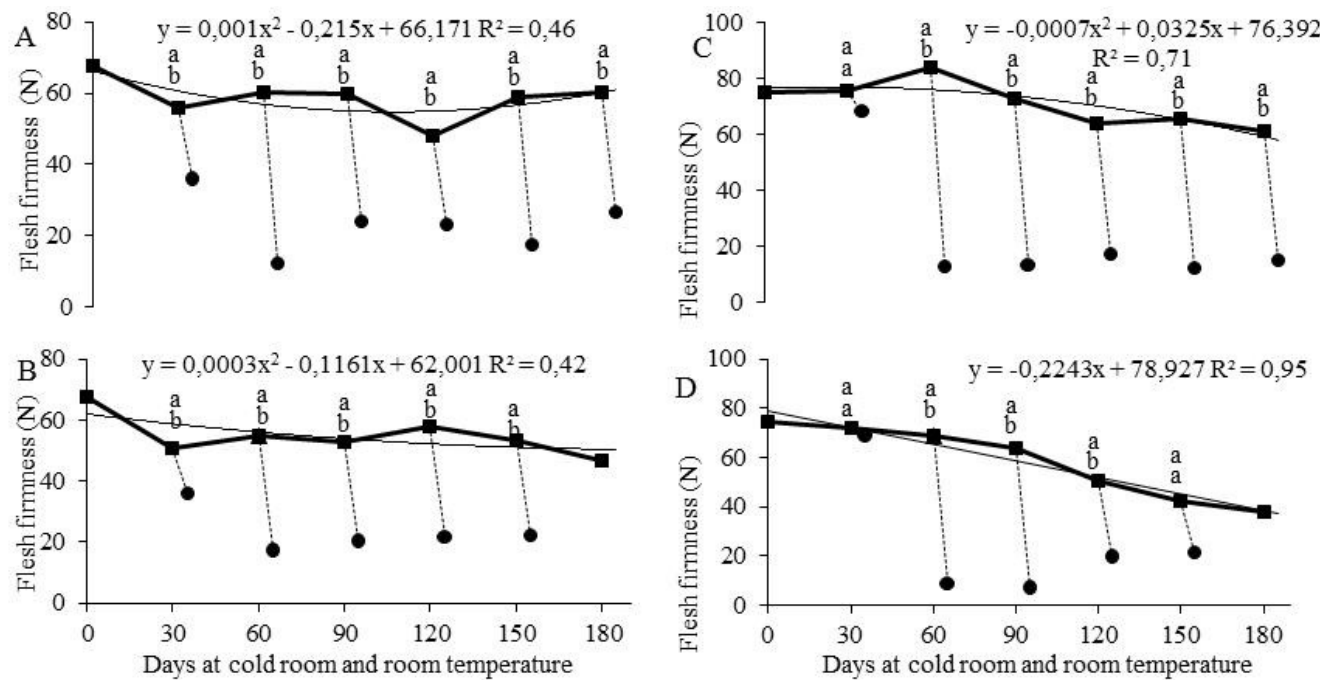

FIGURE 2 - Flesh firmness (N) from 'Rocha' pears in MAP (A) and control (B) and 'Packham's Triumph' pears in MAP (C) and control (D) kept for 180 days in cold storage at $0 \pm 1{ }^{\circ} \mathrm{C}$ and $90 \pm 5 \%$ $\mathrm{RH}$ followed by five days at simulated room temperature $\left(20 \pm 1{ }^{\circ} \mathrm{C}\right)$. Equal letters vertically disposed indicate that the average obtained at room temperature and at $0{ }^{\circ} \mathrm{C}$ do not differ $(\mathrm{p}>$ 0.05 ). Adjusted regression equations for flesh firmness during cold storage is represented by the thinner solid line.
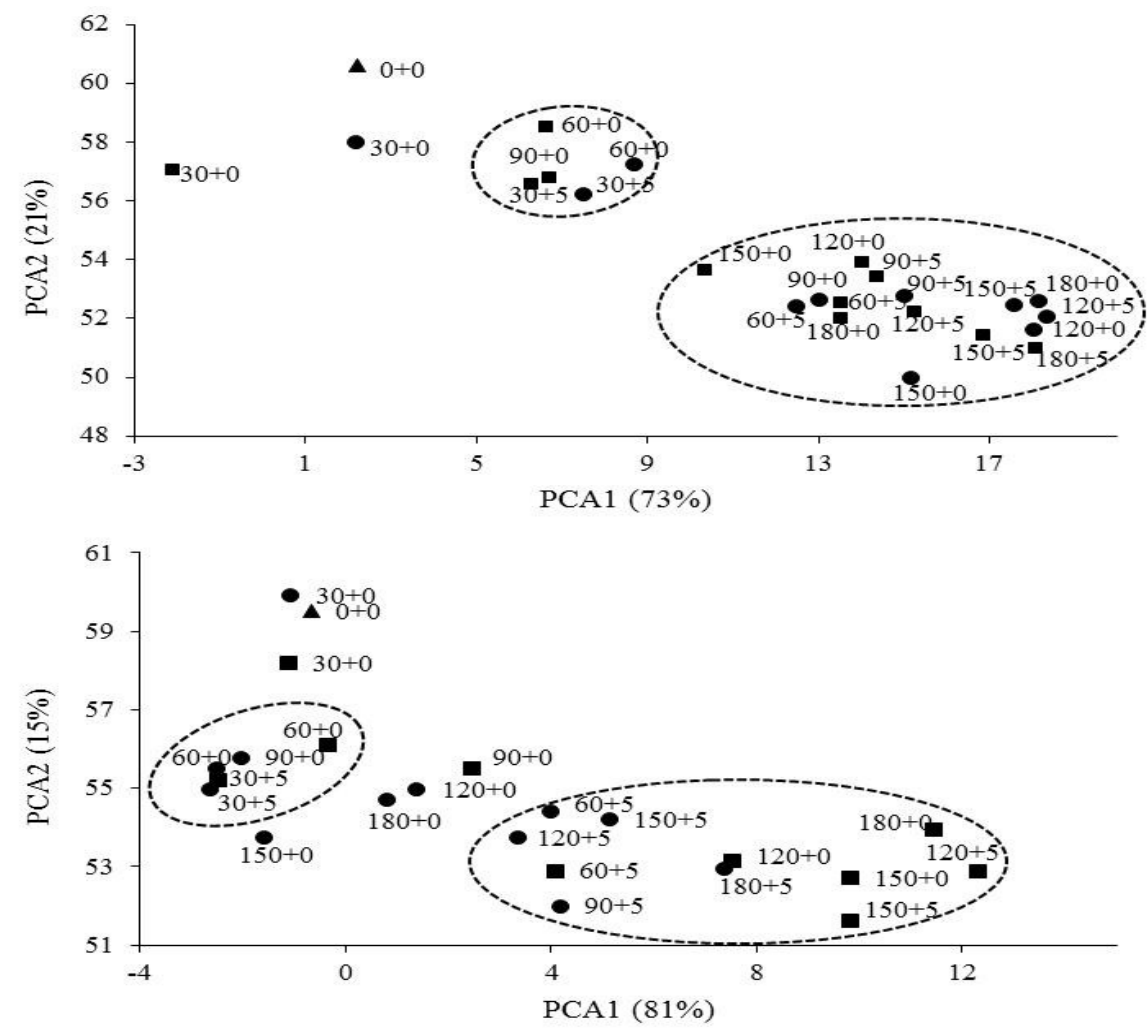

FIGURE 3 - Two-dimensional representation of treatments according to principal components 1 and 2 (PC1 and PC2) for skin color characteristics from 'Rocha' (A) and 'Packham's Triumph' pears (B) kept for 180 days at $0 \pm 1{ }^{\circ} \mathrm{C}$ and $90 \pm 5 \% \mathrm{RH}$ followed by five days at simulated room temperature $\left(20 \pm 1{ }^{\circ} \mathrm{C}\right) .((\boldsymbol{\Delta})$ initial assessment, $(\boldsymbol{\bullet})$ control, $(\bullet)$ MAP (LLDPE (100 $\mu \mathrm{m}), 6 \%$ BIF 1500 additive). 

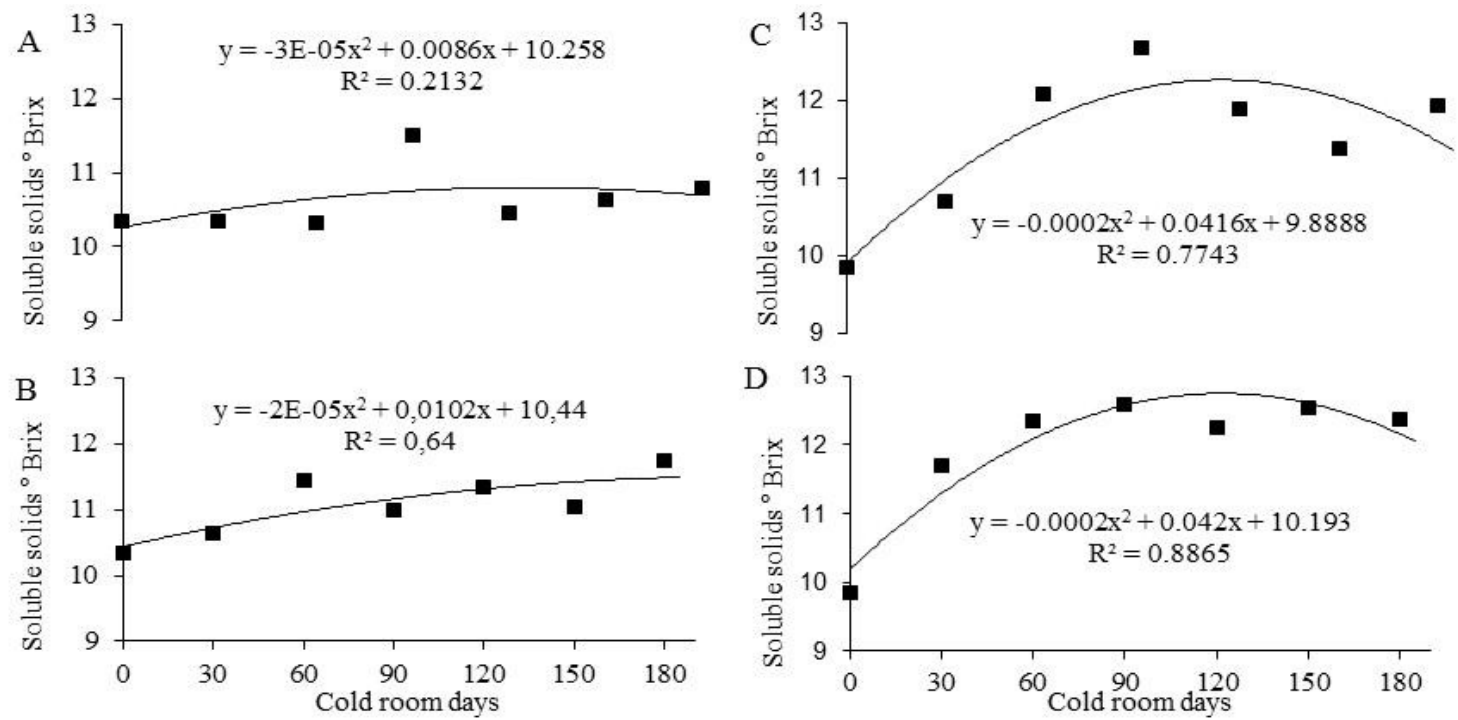

FIGURE 4 - Soluble solids content ( ${ }^{\circ}$ Brix) from 'Rocha' pears in MAP (A) and control (B) and 'Packham's Triumph' pears in MAP (C) and control (D) kept for 180 days in cold storage at $0 \pm 1{ }^{\circ} \mathrm{C}$ and $90 \pm 5 \%$ RH.
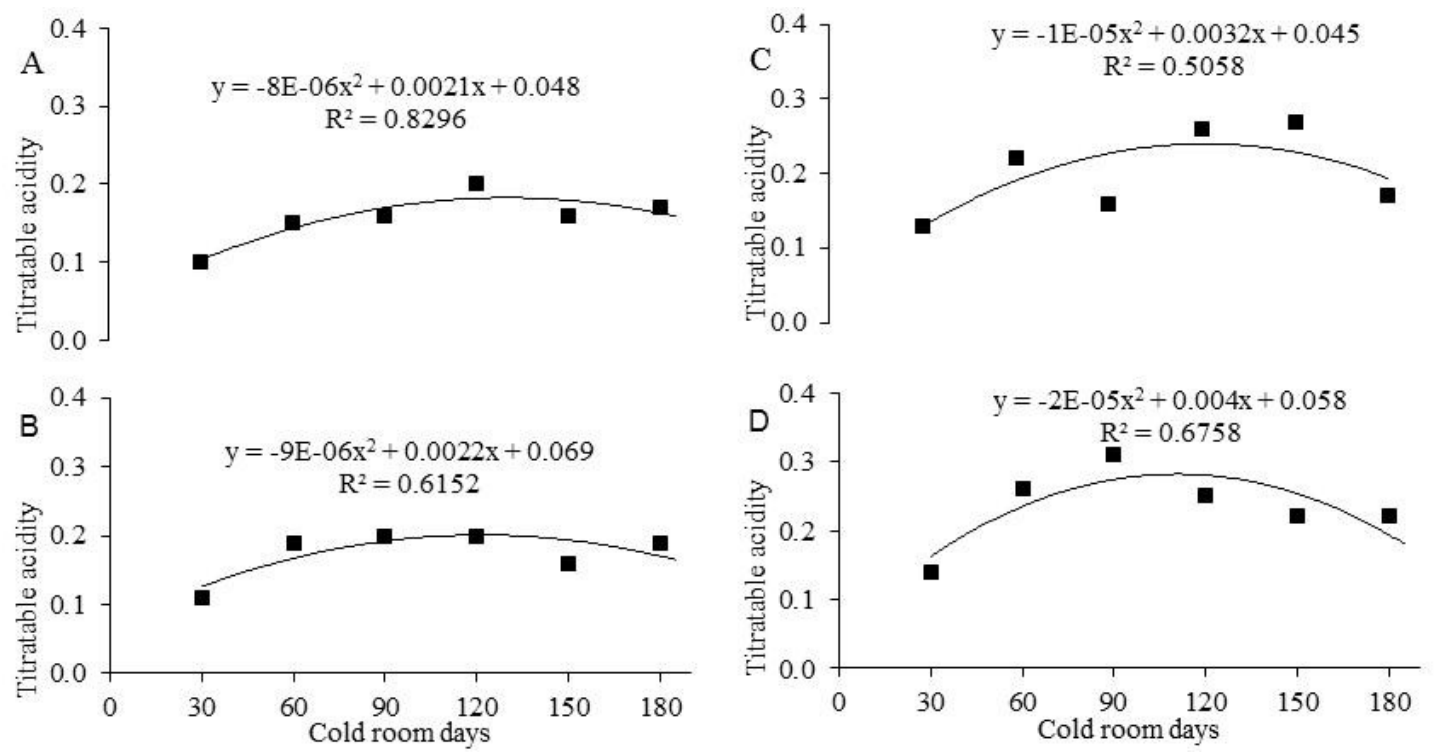

FIGURE 5 - Titratable acidity (\% malic acid) from 'Rocha' pears in MAP (A) and control (B) and 'Packham's Triumph' pears in MAP (C) and control (D) kept for 180 days in cold storage at $0 \pm 1{ }^{\circ} \mathrm{C}$ and $90 \pm 5 \% \mathrm{RH}$. 


\section{CONCLUSION}

Modified atmosphere provided by linear low density polyethylene packaging $(100 \mu \mathrm{m})$ with $6 \%$ $\mathrm{BI}$ additive provides the extension of 30 days in the cold storage for 'Rocha' and 60 days for 'Packham's Triumph' pears.

\section{REFERENCES}

ALMEIDA, D. Fisiologia das alterações de cor. 2004. Disponível em: <http://dalmeida.com/ poscolheita/Cor1.pdf $>$. Acesso em: 30 abr. 2012.

ANP - ASSOCIAÇÃO NACIONAL DE PRODUTORES DE PERA ROCHA. Caderno de especificações pera Rocha do Oeste: denominação de origem. Cadaval, 1997. 28p. Disponível em: $<$ http://ec.europa.eu/agriculture/quality/door/ documentDisplay.html?c > . Acesso em: 16 nov. 2015.

CALVO, G.; SALVADOR, M.E.; SANCHEZ, E. Control of superficial scald in 'Beurre d'Anjou' pears with low oxygen levels. Acta Horticulture, The Hague, v.596, p.879-882, 2002.

CHENG, Y. A. B.; LIU, L. A. B.; ZHAO, G. C.; SHEN, C. A. B.; YAN, H. A. B.; GUAN, J. A. B.; YANG, K. A. The effects of modified atmosphere packaging on core browning and the expression patterns of PPO and PAL genes in 'Yali' pears during cold storage. Food Science and Technology, New York, v.60, p.1243-1248, 2015. doi:10.1016/j. lwt.2014.09.005

CHITARra, M. L. F.; ChitarRA, A. B. Póscolheita de frutos e hortaliças: fisiologia e manuseio. Lavras: UFA, 2005.

CIPRIANI, R. Tendências e estratégias de mercado para a cultura da pereira. In: REUNIÃO TÉCNICA DA CULTURA DA PEREIRA, 5., 2014, Lages. Anais... Lages: CAV/UDESC, 2014. p.106-110.

ELGAR, H.J.; WATKINS, C.B.; MURRAY, S.H.F.; GUNSON, A. Quality of 'Buerre Bose' and 'Doyenne du Cornice' pears in relation to harvest date and storage period. Postharvest Biology Technology, Amsterdam, v.10, p.29-37, 1997.
FERREIRA, V.L.P.; ALMEIDA, T.C.A.; PETTINELLI, M.L.C.; SILVA, J.B.P.; BARBOSA, E. M. M. Análise sensorial testes discriminativos e afetivos. Campinas: SBCTA, 2000. p.127.

IAL - Instituto Adolfo Lutz. Physicochemical methods for food analysis. São Paulo, 2005. 1018p.

ISIDORO, N.; ALMEIDA, D.P.F. Farnesene, conjugated trienols, and superficial scald in 'Rocha' pear as affected by 1-mithylcyclopropene and diphenylamine. Postharvest Biology and Technology, Amsterdam, v.42, p.49-56, 2006.

MAHAJAN, B.V.C.; SINGH, K.; DHILLON, W.S. Effect of 1-methylcyclopropeno (1-MCP) on storage life and quality of pear fruit. Journal Food Science Technology, Mysore, v.47, n.3, p.351-354, 2010.

NATH, A.; BIDYUT, C.; DEKA, A.S.; PATEL, R.K.; PAUL, D.; MISRA, L.K.; OJHA, H. Extension of shelf life of pear fruits using different packaging materials. Journal Food Science Technology, Mysore, v.49, n.5, p.556-563, 2011.

WANG, Y.; SUGAR, D. Ripening behavior and quality of modified atmosphere packed 'Doyenne du Comice' pears during cold storage and simulated transit. Postharvest Biology and Technology, Amsterdam, v.81, p.51-59, 2013.

WREGE, M.S.; HERTER, F.G.; CAMELATTO, D.; REISSER JÚNIOR, C.; GARRASTAZU, M.C.; FLORES, C.A.; IUCHI, T.; BERNARDI, J.; VERÍSSIMO, V.; MATZENAUER, R. Zoneamento agroclimático para pereira no Rio Grande do Sul. Pelotas: Embrapa Clima Temperado, 2006. 29p. (Documentos, 182).

VILLALOBOS-ACUNÃ, M.; MITCHAM, E.J. Ripening of European pears: The chilling dilemma. Postharvest Biology and Technology, n.49, p.187200, 200

ZHU, D.S.; LV, J.Y.; LIANG, J.Y.; CAO, X.; FENG, X.Q.; LI, J.R. Effects of different packaging materials on red fragrant pear during postharvest modified atmosphere storage. Advanced Materials Research, Zug, v.1010-1012, p.1805-1809, 2014.

ZUCOLOTO, M. Amadurecimento e conservação pós-colheita de peras Europeias produzidas o Brasil. 129 f. 2012. Tese (Doutorado em Fitotecnia) - Universidade Federal de Viçosa, Viçosa, 2012. 